\title{
Micro-RNAs: targets for enhancing osteoblast differentiation and bone formation
}

\author{
Hanna Taipaleenmäki ${ }^{1,2}$, Lea Bjerre Hokland ${ }^{1}$, Li Chen ${ }^{1}$, Sakari Kauppinen ${ }^{3,4}$ and Moustapha Kassem ${ }^{1,5}$ \\ ${ }^{1}$ Molecular Endocrinology Laboratory (KMEB), Department of Endocrinology and Metabolism, Medical Biotechnology Center, Odense University Hospital, \\ University of Southern Denmark, SDU, DK-5000 Odense C, Denmark, ${ }^{2}$ Department of Medical Biochemistry and Genetics, University of Turku, Turku, \\ Finland, ${ }^{3}$ Santaris Pharma, Kogle Allé 6, DK-2970 Horsholm, Denmark, ${ }^{4}$ Copenhagen Institute of Technology, Aalborg University, Lautrupvang 15 , \\ DK-2750 Ballerup, Denmark and ${ }^{5}$ Stem Cell Unit, Department of Anatomy, College of Medicine, King Saud University, KSA, Riyadh, Saudi Arabia \\ (Correspondence should be addressed to M Kassem at Molecular Endocrinology Laboratory (KMEB), Department of Endocrinology and Metabolism, \\ Odense University Hospital; Email: mkassem@health.sdu.dk)
}

\begin{abstract}
Osteoblast differentiation and bone formation (osteogenesis) are regulated by transcriptional and posttranscriptional mechanisms. Recently, a novel class of regulatory factors termed micro-RNAs (miRNAs) has been identified as playing an important role in the regulation of many aspects of osteoblast biology including proliferation, differentiation, metabolism and apoptosis. Also, preliminary data from animal disease models suggest that targeting miRNAs in bone can be a novel approach to increase bone mass. This review highlights the current knowledge of miRNA biology and their role in bone formation and discusses their potential use in future therapeutic applications for metabolic bone diseases.
\end{abstract}

European Journal of Endocrinology 166 359-371

\section{Introduction}

Osteoblasts are bone-forming cells that are responsible for bone growth during development and bone formation during remodelling of the post-natal skeleton (1). Osteoblasts originate from stem cells within the bone marrow stroma lying on the abluminal surface of bone marrow sinusoids and are termed bone marrow stromal (skeletal or mesenchymal) stem cells (2). Understanding the mechanisms mediating osteoblast differentiation from mesenchymal stem cells (MSC) as well as regulation of osteoblastic cell functions is a prerequisite for developing new strategies to enhance bone formation and to treat systemic bone diseases such as osteoporosis $(3,4)$.

Throughout recent years, extensive molecular and genetic studies have unravelled several genetic and epigenetic mechanisms involved in osteoblast differentiation and functions. Differentiation of MSC into mature osteoblastic cells and regulation of osteoblast functions involve highly regulated processes mediated by a large number of hormones and locally produced growth factors. Regulatory factors for osteoblastic phenotype include the essential transcription factors, Runx $2 / \mathrm{Cbfa}-1$ and osterix/SP7 (5, 6, 7), and major signalling pathways, bone morphogenetic protein (BMP), Wnt and notch $(8,9$, $10,11,12)$, as well as other growth factor-mediated kinase signalling pathways (13). Emerging evidence reveals an additional level of regulation that is mediated by small non-coding single-stranded RNAs termed micro-
RNAs (miRNAs) $(14,15)$. This review highlights the current knowledge about miRNAs and their involvement in bone development, osteoblast differentiation and functions. It also discusses the future potential of miRNA targeting to treat metabolic bone diseases.

\section{miRNA biogenesis}

miRNAs are an abundant class of evolutionarily conserved, short ( $\sim 22 \mathrm{nt}$ long), single-stranded RNA molecules that have emerged as important posttranscriptional regulators of gene expression (16). The founding members of the miRNA class, lin- 4 and let-7, were discovered in Caenorhabditis elegans to regulate the developmental timing and progression of the nematode life cycle $(17,18,19)$. Later studies have demonstrated that miRNAs are widely expressed in multicellular animals (metazoan eukaryotes) and plants (20). Most metazoan miRNAs bind to partially complementary sites in the 3'-UTRs of the target mRNAs, and thereby inhibit protein synthesis by translational repression and/or mRNA degradation. Perfect complementarity between the miRNA and its target site, as is the case for most plant miRNAs, leads to cleavage of the mRNA by miRNA-induced silencing complex (mRISC) (21).

Most miRNA genes are located in regions distant from annotated genes, suggesting that they derive from independent transcription units $(22,23)$. A minority of miRNA genes are in the introns of protein-coding 
genes, preferentially in the same orientation as the mRNA, indicating that they are processed from the introns rather than transcribed from their own promoters $(22,24)$. In addition, a significant number of miRNA genes are clustered in the genome and transcribed as a multicistronic primary transcript. The miRNAs within the clusters are often functionally related $(17,25)$.

miRNAs are processed through a series of posttranscriptional biogenesis steps (26) (Fig. 1). They are transcribed in the nucleus by RNA polymerase II as a long primary miRNA (pri-miRNA) transcript consisting of the mature miRNA in an elongated RNA hairpin structure containing a loop structure directing its cleavage $(27,28)$. This loop is recognised by the RNase III family nuclease, Drosha, which is present in the $\sim 500 \mathrm{kDa}$ 'microprocessor complex' containing Drosha and double-stranded RNA binding protein (RBP), DGCR8, in humans or its homologue, Pasha, in Drosophila melanogaster and C. elegans $(29,30)$. Drosha cleaves the pri-miRNA into a 70 nt-long stem-loop structure called precursor miRNA (pre-miRNA) (31). The pre-miRNA is actively transported from the nucleus to the cytoplasm by Ran-GTP-dependent nuclear export factor, exportin-5 $(32,33)$.

In the cytoplasm, the pre-miRNA is loaded into a complex of RNAse III endonuclease Dicer and TRBP/ Loquacious (34). This complex cleaves the loop from the pre-miRNA to produce a double-stranded structure composed of the miRNA and antisense miRNA* (35). The miRNA* strand is typically degraded, and the $\sim 22$ nt-long mature miRNA strand is incorporated into the argonaute protein (Ago 2)-containing ribonucleoprotein complex known as mRISC $(36,37)$. The mature
miRNA guides the RISC complex to the UTR of its target mRNA $(21,38)$. The seed sequence, comprising nucleotides $2-8$ at $5^{\prime}$-end of the mature miRNA, is important for binding of the miRNA to its target site in the mRNA (39). Association of miRNA with its target results in mRNA cleavage or repression of translation $(40,41,42)$. Recently, mRNA decay was suggested as a predominant reason for decreased protein levels of a target gene (43).

\section{miRNA function}

To date, 1424 miRNAs have been identified in human cells and each is predicted to regulate several target genes $(44,45)$. Computational predictions indicate that more than $50 \%$ of all human protein-coding genes are potentially regulated by miRNAs $(39,46)$. The abundance of mature miRNAs varies extensively from as few as ten to more than 80.000 copies in a single cell, which provides a high degree of regulation flexibility (47). The regulation exerted by miRNA is reversible, as feedback/forward regulatory loops have been shown to exert modifying effects during translation (48).

miRNAs play critical roles in diverse biological and cellular processes including metabolism, differentiation and apoptosis. Aberrant miRNA expression has been implicated in the pathogenesis of a large number of human diseases including cancer, diabetes, neurological disorders, heart failure, pulmonary hypertension and autoimmune diseases due to dysfunction of their target genes $(49,50,51,52)$. In addition, numerous miRNAs are associated with development and progression of cancer. Such cancer-associated miRNAs have been

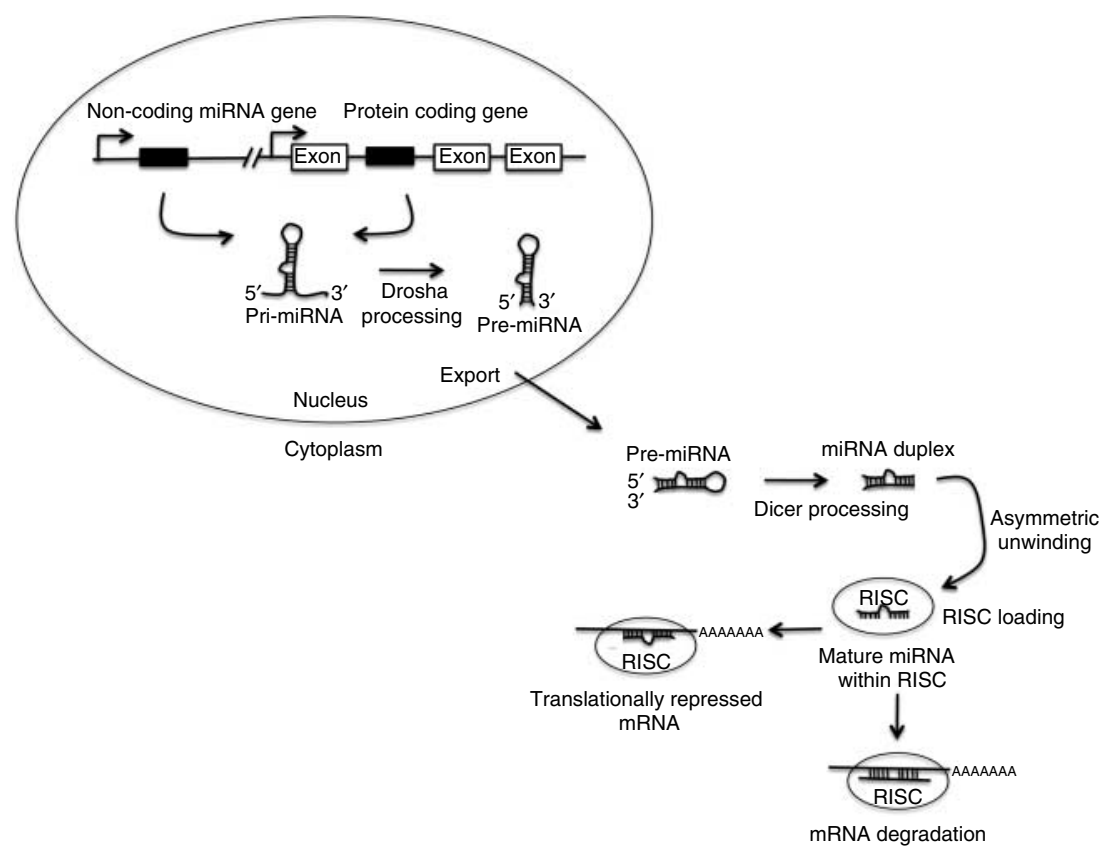

Figure 1 miRNA biogenesis and function. miRNAs are transcribed as long precursors (pri-miRNAs) that are cleaved by Drosha to yield stem-loop pre-miRNAs. The premiRNAs are translocated from the nucleus to the cytoplasm by the exportin- 5 complex. In the cytoplasm, pre-miRNAs are processed by Dicer into around 22-nucleotide long mature miRNAs. These are incorporated into the RNA-induced silencing complex (RISC), which guides the miRNAs to their target mRNAs, resulting in mRNA cleavage or repression of translation. miRNA, micro-RNA; RISC, RNA-induced silencing complex. 
reported as both tumour suppressors and oncogenes (53). Due to aberrant miRNA expression in human disorders, miRNA expression profiling may be useful as diagnostic or prognostic tools and can help in treatment decisions in cancer and other diseases (54).

miRNAs are essential for vertebrate development, proven by studies demonstrating that universal disruption of Dicer in mice results in embryonic lethality and depletion of pluripotent stem cells, and deficiency of Argonaute results in severe defects in development (55, 56). Tissue-specific disruption of Dicer leads to developmental defects, and in most of the examined tissues, increased cell death, indicating that miRNAs play a crucial role in the development of various tissues including the heart, brain, muscle, lungs, limbs and T cells among others $(57,58)$.

\section{Mechanisms of action of miRNAs}

Mammalian miRNAs tend to have several isoforms (paralogues) encoded from one or more chromosome, suggesting that they are functionally redundant $(59,60)$. By differences in their expression pattern and $3^{\prime}$-end binding, they exert variable roles in vivo (61). Regulation is mainly exerted by binding to $3^{\prime}$-UTR of target mRNA, but miRNA binding to other positions on the target mRNA, e.g. in $5^{\prime}$-UTR or coding sequence and CDS region of transcription factors has also been reported $(62,63,64)$. mRNA targeting by miRNA is highly specific, and even rare splice variants can be distinguished by spanning of exon-exon junctions (65). Interestingly, besides generally promoting mRNA cleavage or translational repression, miRNA binding to $3^{\prime}$ UTR can also induce translation of target mRNAs. Few miRNAs have been identified to repress translation during cell proliferation but to activate translation on cell cycle arrest by directing AGO-containing protein complexes to AU-rich elements in the $3^{\prime}$-UTR (66).

\section{Target prediction and validation}

Several algorithms are provided online for the prediction of mRNA targets (39). PicTar and TargetScanS are the most commonly used and have been reported to produce comparable predictions of targets (67). Computational target prediction is primarily based on potential pairing of the miRNA seed sequence to a complementary site in the $3^{\prime}$-UTR of a target mRNA according to specific base-pairing rules. Another criteria for target prediction is cross species conservation of at least five species for the miRNA binding mRNA $3^{\prime}$-UTR target site.

Computational algorithms predict that over $50 \%$ of all human protein-coding genes may be regulated by miRNAs and that a single miRNA can have hundreds of target genes (46). A conventional low-throughput approach to validate miRNA targets is to clone the target 3 '-UTR into a luciferase reporter plasmid and detect luciferase activity in the presence of specific miRNA precursor and/or inhibitor. Novel immunoprecipitation (IP)-based methods were recently developed for target validation. Karginov et al. (68) combined RISC purification with microarray analysis of RISC-bound mRNAs. Ago HITS-CLIP method combines high-throughput sequencing to cross-linking IP to identify functional interaction sites between miRNA and target mRNA. Native Ago protein-RNA (miRNA or mRNA) complexes were covalently cross-linked by HITS-CLIP and the two data sets were combined with bioinformatics analysis. As a result, genome-wide interaction maps were generated for the 21 most abundant miRNAs in mouse brain (69). Cross-linking RBP and miRNA-containing ribonucleoprotein complexes (miRNPs) in a cell-type dependent fashion was used to transcriptome-wide identify miRNA-target interactions by a method called PAR-CLIP (70).

In RNP-IP approach, miRNA-RISC complexes were isolated and miRNA-bound mRNA transcripts were identified by amplification with seed sequence and 3'-UTR-derived primers (71). With RNP-IP method, Hassan et al. validated targets for two Bmp2-responsive miRNAs, miR-27a and miR-Let7/98, in mouse preosteoblastic cells. Hlx was identified as target for miR-27a and miR-Let7/98 family was shown to target several osteoblast-associated genes including IGF2BP1, COL1A1 and TGFBR1. As a single miRNA may target several genes, it is evident that in many biological processes targeting only one gene is not sufficient for mediating miRNA-related biological functions. In support of this, Li et al. (72) demonstrated miR-29b as a key regulator of osteoblast differentiation by directly targeting several inhibitors of osteogenesis, histone deacetylase (HDAC4), TGF-b3, ACVR2 and catenin$\beta$-interacting protein 1 (CTNNBIP1) and thus promoting osteoblast phenotype.

\section{Detection of miRNAs}

miRNA profiling is a commonly used method for genome-wide miRNA expression analysis. Commercial oligonucleotide-based miRNA arrays provide an efficient platform for high-throughput profiling of miRNA expression (73). Most of the commercially available arrays are based on miRNAs available in miRBase (http://www.mirbase.org/) database that is updated regularly due to increasing number of identified miRNAs. miRNA expression profiling has been performed for various cell lines during the osteoblast differentiation process. In global microarray profiling in C2C12 mesenchymal cells, most of the significantly changed miRNAS were down-regulated in response to BMP2 $(74,75)$. In hMSCs, miRNA profiling with locked nucleic acid (LNA)-based microarray (76) revealed 33 miRNAs being significantly altered between undifferentiated and differentiated cells (77). Among them, 
Table 1 miRNAs involved in osteoblastogenesis.

\begin{tabular}{|c|c|c|c|c|}
\hline microRNA & Target & Supporting observations & Cell source & References \\
\hline Let-7 & - & $\begin{array}{l}\text { More regulated in osteogenic than } \\
\text { adipogenic and chondrogenic cells }\end{array}$ & hMSC & $(128)$ \\
\hline miR-9, miR-98 & & $\begin{array}{l}\text { Clinically identified as varying between } \\
\text { OA and normal tissue }\end{array}$ & Human tissues & $(117)$ \\
\hline $\mathrm{miR}-20 b^{\S}$ & $\begin{array}{l}\text { PPAR } \\
\text { Bambi } \\
\text { Crim1 }\end{array}$ & Upregulates BMP2 and Runx2 & hMSC & $(129)$ \\
\hline miR-23a $\sim 27 a \sim 24-2$ & Runx2 & $\begin{array}{l}\text { Down-regulate SATB2 that synergizes } \\
\text { with Runx2 to facilitate bone formation }\end{array}$ & rOB, МС3Т3-E1 & $(105)$ \\
\hline miR-26a & SMAD1 & $\begin{array}{l}\text { Decreases SMAD1 protein levels by } \\
\text { diminishing availability to active SMAD1 }\end{array}$ & hASC & $(97)$ \\
\hline $\operatorname{miR}-27^{\S}$ & APC & $\begin{array}{l}\text { Activates Wnt signalling through } \\
\text { accumulation of } \beta \text {-catenin }\end{array}$ & hFOB & $(130)$ \\
\hline \multirow[t]{2}{*}{ miR-29a } & Osteonectin, & $\begin{array}{l}\text { Decreases ON levels by } 3^{\prime} \text {-UTR binding, } \\
\text { down-regulates }\end{array}$ & hFOB & $(102,103)$ \\
\hline & $\begin{array}{l}\text { sFRP2, Dkk1 } \\
\text { Kremen }\end{array}$ & Wnt antagonists & $\begin{array}{l}\mathrm{hOB} \\
\mathrm{mOB}\end{array}$ & \\
\hline \multirow[t]{2}{*}{$\operatorname{miR}-29 b^{\S}$} & $\begin{array}{l}\text { HDAC4, TGF- } \beta 3, \\
\text { ACVR2A, } \\
\text { CTNNBIP1, } \\
\text { DUSP2 }\end{array}$ & $\begin{array}{l}\text { Up-regulated at the matrix maturation } \\
\text { stage, down-regulated during } \\
\text { mineralisation } \\
\text { Down-regulates several inhibitors of } O B \\
\text { differentiation }\end{array}$ & $\begin{array}{l}\text { mBMSC, } \\
\text { МС3T3-E1 }\end{array}$ & $(72,110)$ \\
\hline & $\begin{array}{l}\text { Col1A1 } \\
\text { Col5A3 } \\
\text { Col4A2 }\end{array}$ & & & \\
\hline miR-30c, miR-34 & Runx2 & $\begin{array}{l}\text { Group of miRNAs target Runx2 and inhibit } \\
\text { osteoblastogenesis }\end{array}$ & МС3Т3-E1 & $(94)$ \\
\hline $\mathrm{miR}-125 \mathrm{~b}$ & ErbB2 & Inhibits OB differentiation & ST2 & (131) \\
\hline miR-133 & Runx2 & $\begin{array}{l}\text { Belongs to group of Runx2 targeting } \\
\text { miRNAs }\end{array}$ & $\mathrm{C} 2 \mathrm{C} 12$ & $(75,94)$ \\
\hline miR-135 & SMAD5, Runx2 & $\begin{array}{l}\text { Decreases SMAD5 phosphorylation and } \\
\text { Runx2 }\end{array}$ & С2C12, МС3Т3 & $(75,94)$ \\
\hline miR-135b & & Decreases mineralisation & hUSSC & $(132)$ \\
\hline miR-138 & PTK2 & $\begin{array}{l}\text { Inhibits FAK/ERK pathway and Runx2 } \\
\text { activation }\end{array}$ & hMSC & $(77)$ \\
\hline miR-140 & $\begin{array}{l}\text { HDAC4 } \\
\text { ADAMTS5 }\end{array}$ & $\begin{array}{l}\text { Accumulates in cartilage, down-regulated } \\
\text { in } \mathrm{OA}\end{array}$ & Mouse embryos & $(109,120,121)$ \\
\hline miR-141, miR-200a & DIx5 & Down-regulate DIx5 and osterix & МС3Т3-E1 & $(101)$ \\
\hline miR-146 & - & $\begin{array}{l}\text { Inhibits NF- } \kappa B \text { activation and inhibits } \\
\text { mineralisation }\end{array}$ & hASC & $(133)$ \\
\hline $\begin{array}{l}\text { miR-148b } b^{\S}, \mathrm{miR}-27 a \\
\text { miR-489 }\end{array}$ & & $\begin{array}{l}\text { miR-27a and miR-489 inhibit osteogenesis } \\
\text { through repressing grancalcin }\end{array}$ & hMSC & $(108)$ \\
\hline \multirow[t]{2}{*}{ miR-155 } & SMAD1, SMAD5 & $\begin{array}{l}\text { Inhibits endogenous SMADs and } \\
\text { decreases ID3 }\end{array}$ & MUTU I, A5499 & $(134)$ \\
\hline & & $\begin{array}{l}\text { Reduces osteoclast number and causes } \\
\text { trabeculae thickening }\end{array}$ & $\begin{array}{l}\text { Dicer deficient } \mathrm{OB} \\
\text { and OC }\end{array}$ & $(135)$ \\
\hline $\operatorname{miR}-196 a^{\S}$ & HoxC8 & $\begin{array}{l}\text { Down-regulates HoxC8, a transcriptional } \\
\text { repressor of osteogenesis }\end{array}$ & hASC & $(106)$ \\
\hline miR-199a & SMAD1 & $\begin{array}{l}\text { Regulates chondrogenesis and may play } \\
\text { an important role in osteogenesis }\end{array}$ & $\mathrm{C} 3 \mathrm{H} 10 \mathrm{~T}$ & $(136)$ \\
\hline miR-199a, miR-346 & LIF & $\begin{array}{l}\text { Decrease LIF and induce differentiation } \\
\text { by unidentified pathway }\end{array}$ & hBMSC & $(137)$ \\
\hline miR-204, miR-205 & Runx2 & Belong to group of Runx2 targeting miRNAs & MC3T3 & $(94)$ \\
\hline miR-206 & Cx43 & $\begin{array}{l}\text { Down-regulates osteocalcin } \\
\text { BMP2 prevents Pri-miR-206 maturation } \\
\text { process }\end{array}$ & $\begin{array}{l}\text { C2C12 } \\
\text { MC3T3-E1, ST2 }\end{array}$ & $(74,138)$ \\
\hline miR-208 & Ets1 & $\begin{array}{l}\text { Down-regulates OPN, Runx2, PTHrP, } \\
\text { tenascin-C and type I procollagen }\end{array}$ & $\begin{array}{l}\text { MC3T3-E1 } \\
\text { mOB }\end{array}$ & $(139)$ \\
\hline $\operatorname{miR}-210^{\S}$ & ActR1B & $\begin{array}{l}\text { Inhibits the TGF- } \beta \text { /activin signalling } \\
\text { pathway }\end{array}$ & ST2 & $(107)$ \\
\hline $\begin{array}{l}\text { miR-217, miR-218, } \\
\text { miR-338 }\end{array}$ & Runx2 & Belong to group of Runx2 targeting miRNAs & МС3Т3-E1 & $(94)$ \\
\hline miR-335-5p & Dkk1 & $\begin{array}{l}\text { Promotes osteogenesis by activating } \\
\text { Wnt signalling }\end{array}$ & $\begin{array}{l}\text { MC3T3-E1, } \\
\text { MLO-Y4 }\end{array}$ & $(78)$ \\
\hline miR-378 & GalNT-7 & Increases nephronectin & МС3Т3-E1 & $(140)$ \\
\hline
\end{tabular}


Table 1 Continued

\begin{tabular}{lllll}
\hline microRNA & Target & Supporting observations & Cell source & References \\
\hline miR-2861§ & HDAC5 & $\begin{array}{l}\text { Causes Runx2 accumulation } \\
\text { Mutations cause osteoporosis in humans }\end{array}$ & ST2 & (63) \\
miR-3960§ & Hoxa2 & ST2 & (104) \\
\hline
\end{tabular}

C2C12, murine myoblast cell line; MC3T3-E1, murine pre-osteoblastic cell line; 3T3-L1, sub-line of murine embryonic fibroblast cell line; ST2, murine fetal liverderived stromal cell line; hASC, human adipose tissue-derived stem cells; hFOB, human fetal osteoblasts; hPLSC, human periodontal ligament stem cells; hUSSC, human unrestricted somatic stem cells; m- and hBMSC, murine and human bone marrow mesenchymal stem cells; OB, osteoblast; OC, osteoclast;

$\mathrm{OA}$, osteoarthritis. ${ }^{\S}$, microRNAs that positively regulate osteogenesis.

an almost equal number of miRNAs was up- and down-regulated during differentiation (15 up- and 18 down-regulated). In contrast to MSC, a great number of miRNAs are up-regulated during osteoblast maturation and mineralisation. In preosteoblastic calvarial cells, the majority of miRNAs ( 58 of 68 significantly altered miRNAs) were up-regulated during mineralisation stage (72), and in mouse pre-osteocyte-like MLO-A5 cells, 14 out of 20 miRNAs were up-regulated in response to ascorbic acid treatment (78). One of the most sensitive methods for miRNA profiling and identification of novel miRNAs is ultra high-throughput sequencing or 'deep sequencing' (79). Deep sequencing produces millions of sequencing reads encompassing the transcriptome of choice for mapping and quantitative and qualitative analysis of small RNA fragments (80). Several programs are available to distinguish miRNA sequences from other non-coding RNAs, mRNAs and degraded RNA, including publicly available programs miRDeep and miRanalyser $(81,82)$.

Validation of miRNA expression data is commonly performed with small RNA northern blots, RNAse protection assays or qRT-PCR analysis. In situ hybridisation provides an approach to detect expression and in vivo distribution of miRNA. Wienholds et al. (83) compared in situ expression patterns with expression profiles obtained from miRNA array in zebrafish and were able to confirm more than $77 \%$ of the in situ expression patterns by at least one microarray data set. By in situ hybridisation, Inose et al. (74) confirmed miRNA array observations and detected miR-206 expression in perichondrium in E14.4 old mice with decreased expression during in vivo skeletogenesis. miR335-5p was observed in perichondrial cells in E13.5 embryos and in E16.5 in mandible and in osteoblasts aligning on the surface of cranial base cartilage supporting its role as a positive regulator of osteogenesis (78).

\section{Regulation of osteoblast differentiation and bone development by miRNA}

The osteogenic differentiation of MSCs is a coordinated process defined by four stages: cellular commitment, proliferation, matrix maturation and mineralisation. Osteoblast differentiation is tightly regulated by hormones such as parathyroid hormone and by local growth factors including BMPs, IGF and FGFs $(84,85$, 86). These factors activate specific intracellular pathways that trigger the expression of several osteoblast-specific transcription factors. Runx2 is an essential transcription factor for the differentiation of MSCs into the osteogenic lineage and for bone formation $(87,88)$. It regulates the expression of several osteoblastic genes, such as COL1A1, alkaline phosphatase $(A L P L)$, bone sialoprotein (IBSP), SPP1 (osteopontin) and BGLAP (osteocalcin) (89, 90). Runx2 transcriptional activity is negatively regulated by HDACs. Osterix/SP1 is another crucial transcription factor required for the differentiation of preosteoblasts into fully functioning osteoblasts (91). Other important transcription factors involved in osteoblast differentiation include activating transcription factor 4, transcriptional modulator (TAZ), TWIST and homeodomain proteins Msx1, Msx2, Dlx5 and Dlx6 (6, 7, 92).

\section{Role of miRNAs in mesenchymal precursor cell differentiation}

An increasing number of miRNAs have been identified to regulate osteoblast differentiation and bone formation positively by targeting negative regulators of osteogenesis or negatively by targeting important osteogenic factors (Table 1 and Fig. 2). Several studies have demonstrated that miRNAs target the principal transcription factors and signalling molecules involved in osteoblast differentiation of MSCs and osteoblast functions (Figs 2 and 3). miRNAs 133 and 204/211 attenuated osteoblast differentiation by directly targeting Runx2 in C2C12 mesenchymal progenitor cells and MSCs respectively $(75,93)$. Recently, a group of 11 miRNAs was discovered to control Runx2 levels during osteoblast and chondrocyte differentiation suggesting complex regulation of lineage commitment by multiple miRNAs targeting key lineage-specific transcription factors (94). In addition, several miRNAs indirectly affect Runx 2 expression or activation to modulate osteoblast differentiation. Focal adhesion kinase is a key activator of extracellular signal-related kinase (ERK) pathway in extracellular matrix (ECM)-induced osteoblast differentiation $(95,96)$. By directly targeting PTK2, a gene encoding FAK, miR-138 was shown to attenuate the ERK-dependent pathway, phosphorylation of 


\begin{tabular}{|c|c|c|c|c|c|}
\hline \multicolumn{3}{|c|}{ Transcription factors } & \multirow{2}{*}{$\begin{array}{c}\text { Growth factors } \\
\text { TGF- } \beta\end{array}$} & \multirow{2}{*}{\multicolumn{2}{|c|}{$\begin{array}{l}\text { Other } \\
\text { HDAC }\end{array}$}} \\
\hline Runx2 & \multicolumn{2}{|c|}{ Osx } & & & \\
\hline $\begin{array}{l}\text { miR-20b } \\
\text { miR-23a } \\
\text { miR-29b } \\
\text { miR-138 } \\
\text { miR-155 } \\
\text { miR-208 } \\
\text { Let-7 } \\
\end{array}$ & $\begin{array}{l}\text { miR-135 } \\
\text { miR-141 } \\
\text { miR-200a } \\
\text { miR-224 }\end{array}$ & & miR-210 & \multicolumn{2}{|l|}{$\begin{array}{l}\text { miR-29b§ } \\
\text { miR-140 } \\
\text { miR-2861§ } \\
\text { Let-7 }\end{array}$} \\
\hline \multicolumn{6}{|c|}{ Immature osteoprogenitors } \\
\hline $\begin{array}{l}\text { Transcription } \\
\text { factors }\end{array}$ & \multicolumn{2}{|c|}{ BMP-signalling } & $\begin{array}{c}\text { Wnt } \\
\text { signalling }\end{array}$ & \multicolumn{2}{|c|}{ ECM proteins } \\
\hline Runx2 & BMPs & Smads & $\begin{array}{c}\text { Wnt } \\
\text { inhibitors }\end{array}$ & Collagens & BSP \\
\hline $\begin{array}{l}\text { miR-23a } \\
\text { miR-30c } \\
\text { miR-34c } \\
\text { miR-133 } \\
\text { miR-135a } \\
\text { miR-135b } \\
\text { miR-204 } \\
\text { miR-205 } \\
\text { miR-217 } \\
\text { miR-338 }\end{array}$ & $\operatorname{miR}-20 b^{\S}$ & $\begin{array}{l}\text { miR-26a } \\
\text { miR-133 } \\
\text { miR-135 } \\
\text { miR-199a }\end{array}$ & $\begin{array}{l}\operatorname{miR}^{2}-27^{\S} \\
\text { miR-29a }^{\S}\end{array}$ & $\begin{array}{l}\text { miR-29b } \\
\text { miR-208 } \\
\text { Let-7 }\end{array}$ & miR-135b \\
\hline
\end{tabular}

Pre-osteoblasts

\begin{tabular}{|l|l|l|l|}
\hline \multicolumn{2}{|c|}{ Transcription factors } & $\begin{array}{c}\text { Wnt } \\
\text { signalling }\end{array}$ & ECM proteins \\
\hline \multicolumn{1}{|c|}{ Runx2 } & Dlx5 & $\begin{array}{c}\text { Wnt } \\
\text { inhibitors }\end{array}$ & Osteocalcin \\
\hline $\begin{array}{l}\text { miR-29b } \\
\text { miR-955 } \\
\text { Let-7 }\end{array}$ & $\begin{array}{l}\text { miR-141 } \\
\text { miR-200a }\end{array}$ & miR-335-5p & miR-206 \\
\hline
\end{tabular}

Mature osteoblasts
Figure 2 Diagrammatic representation of miRNAs regulating osteoblast differentiation. miRNAs are involved in various steps during MSC differentiation to osteoblasts. miRNAs regulate each differentiation step by targeting important transcription factors, growth factors and other molecules. Depending on the target, miRNAs have either a positive or negative effect on osteoblast differentiation. miR, micro-RNA; Osx, osterix; HDAC, histone deacetylase; BMP, bone morphogenetic protein; ECM, extracellular matrix; BSP, bone sialoprotein. §, miRNAs that positively regulate osteogenesis. Red font indicates direct target and black font indicates indirect effect.
Runx2, OSX expression and, subsequently, inhibit osteoblast differentiation and bone formation of MSCs in vitro and in vivo (77). miR-26a and miR-135 functionally repress osteoblast differentiation by targeting Smad1 and Smad5 respectively $(75,97)$.

Since osteoblasts and adipocytes share common stem cells (MSCs), miRNA regulation of OB differentiation may regulate adipocytic differentiation indirectly. miR138 was highly expressed in undifferentiated MSCs and down-regulated upon differentiation to osteoblastic, adipogenic and chondrogenic lineages. Based on its expression profile and functional inhibition of osteogenesis and adipogenesis $(77,98)$, it is thus possible that miR-138 maintains MSCs in undifferentiated stage. Similarly, miR-335 down-regulation was shown to be critical for MSC differentiation, and over-expression of miR-335 inhibited both osteoblastic and adipogenic differentiation of MSCs (99). A hypothetical model was proposed by Tome et al. in which miR-335 is down-regulated in response to tissue damage signals leading to de-repression of its target genes and MSC migration and differentiation. While the abovementioned miRNAs inhibited both osteoblastic and adipogenic differentiation, miR-204/211 and miR-637 were shown to play a role in the inverse relationship between osteoblastogenesis and adipogenesis by targeting Runx2 and Osx respectively (93, 100).

\section{miRNAs regulating osteoblast maturation and function}

In addition to regulating MSC differentiation to osteoblastic lineage, miRNAs contribute to osteoblast maturation (14). miRNAs miR-141 and miR-200a were down-regulated during preosteoblast differentiation and inhibited osteoblastogenesis by targeting Dlx 5 (101). Inose et al. (74) identified miR-206 in perichondral cells and not in mature osteoblast and accordingly demonstrated inhibition of osteoblast maturation and in vivo bone formation with miR-206.

Activation of canonical Wnt signalling is crucial for osteoblast function. miR-335-5p was shown to directly target and down-regulate Wnt inhibitor DKK1, enhance Wnt signalling and promote osteogenesis in a cell- and development-dependent manner (78). miR-29a potentiates osteoblastogenesis by modulating Wnt signalling through a positive feedback loop (102). While canonical Wnt signalling induced miR-29 expression, miR-29 targets negative regulators of Wnt signalling: Dkk1, Kremen and sFRP2, thus further 
A

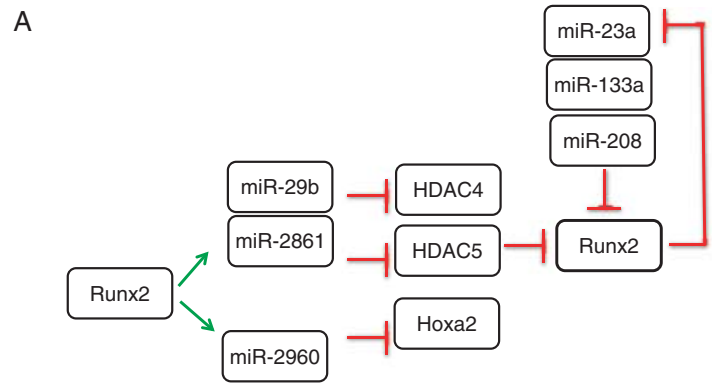

B

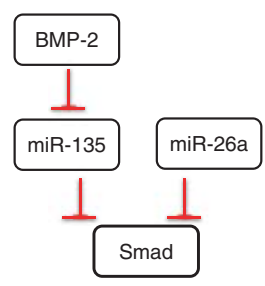

C

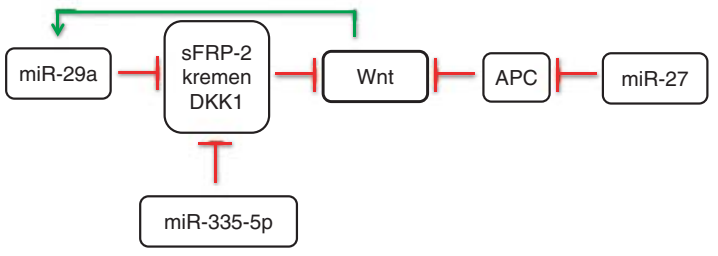

Figure 3 Regulation of Runx2, BMP and Wnt signalling pathways by miRNAs. (A) miRNAs regulate positively and negatively Runx2, the key transcription factor of osteogenesis. Positive regulation of Runx2 is obtained by miRNAs targeting Runx2 inhibitors HDACs. Direct binding of miRNAs to Runx2 $3^{\prime}$-UTR results in negative regulation. Both negative and positive regulatory loops are shown between Runx2 and miRNAs. (B) miRNA regulation of $B M P / S m a d$ signalling results in inhibition of osteoblastogenesis. (C) miRNAs can activate Wnt signalling by targeting Wnt inhibitors. miR-29a expression is activated by Wnt signalling leading to a positive regulatory loop. miR, micro-RNA; HDAC, histone deacetylase; BMP, bone morphogenetic protein; APC, adenomatous polyposis coli. promoting Wnt activity and osteoblast differentiation (103). Additional regulatory loops were recently identified involving miRNAs and Runx2, implying sophisticated regulatory mechanisms between miRNAs and their targets. miR-3960/miR-2861/Runx2 form a positive regulatory loop promoting osteogenesis (104) while the miR-23a-27a-24-2/Runx2/SATB2 loop functions as a negative regulator of the osteoblast differentiation program. However, Runx 2 down-regulates this miR cluster to promote differentiation (105).

Although most of the miRNAs identified thus far negatively regulate osteoblast differentiation, several miRNAs are capable of enhancing osteoblast differentiation and osteogenesis (Table 1). miR-29b, miR-148b, miR-196a, miR-210, miR-335-5p, miR-2861 and miR3960 have been reported to target and cause downregulation of various inhibitors of osteoblast differentiation and hence exert stimulatory effects $(72,102$, $104,106,107,108)$. The effects are applied through several mediators, such as HDAC4, HDAC5, TGF- $\beta 3$, HoxC8, ActR1b, PEX7 and grancalcin, a $\mathrm{Ca}^{2+}$-binding protein abundantly expressed by neutrophils and macrophages. Interestingly, miR-29b exhibits differentiation stage-dependent expression where it is up-regulated during matrix maturation and down-regulated during matrix mineralisation (72). Several inhibitors of osteoblast differentiation were identified as direct targets for miR-29b: HDAC4, TGF- $\beta 3$, activin A receptor type IIA (ACVRA2A) and CTNNBIP1, suggesting that not only multiple proteins but also various signalling pathways can be affected by specific miRNAs.

\section{miRNAs in skeletal development}

The importance of miRNAs in skeletal development has been addressed by generating conditional limb mesenchyme- and osteoblast-specific Dicer knockout mice. The disruption of Dicer in chondrocytes resulted in an abnormal cartilage phenotype with impaired chondrocyte proliferation and accelerated maturation, indicating that miRNAs play a crucial role in chondrogenesis by maintaining chondrocyte proliferation and inhibiting their premature hypertrophy (58). Tuddenham et al. (109) provided evidence for miR140 accumulation in the cartilage of developing long and flat bones of mice embryos. During bone formation, miRNAs are important in two periods of the process: in promoting the osteoblast differentiation and in controlling bone accrual in a post-natal organism (110). Gaur et al. (110) additionally showed that miR-29b and let-7a are up-regulated at matrix maturation stage (d19) and down-regulated during mineralisation (d27) in developing mice. However, our current knowledge on expression and function of specific miRNAs during bone development in vivo is still limited. miR-206 expression was detected in developing mouse embryos with decreased expression during osteoblast differentiation and bone formation. Correspondingly, overexpression of miR-206 resulted in a low bone mass due to defected bone formation in mice (74).

\section{Utility of miRNA targeting for treatment of skeletal diseases}

\section{miRNAs as therapeutic targets}

miRNAs may represent novel therapeutic targets for pharmacological control of bone cell functions and enhancement of bone formation. Several approaches are currently being investigated to be utilised in therapeutic applications (111). By expression of a short hairpin RNA containing either the miRNA from 
a plasmid or viral vector with either a polymerase II or III promoter upstream, Dicer could modify the hairpin structure to produce the mature miRNA (112). The use of miRNA sponges to inhibit miRNA function was first described by Ebert et al. (113). By transfection with a sponge plasmid containing multiple tandem binding sites for specific miRNA(s), cells expressing sponge RNAs sequester the miRNA, thereby preventing the interaction between targets and endogenous miRNAs. Chemically modified antisense oligonucleotides complementary to the mature miRNA (designated as anti-miRs) provide another approach to silence specific miRNA in cultured cells and in vivo (114). Most advanced studies using LNAmodified anti-miRs were performed with miR-122, abundant liver-expressed miRNA. miR-122 binds in the $5^{\prime}$-non-coding region of the hepatitis $\mathrm{C}$ virus $(\mathrm{HCV})$ genome, resulting in the up-regulation of viral RNA levels (115). Targeting miR-122 with anti-miRs resulted in decreased cholesterol levels in mice and African monkeys and was recently shown to lead to long-lasting suppression of HCV (116).

\section{miRNAs as targets in skeletal disease}

Few specific miRNAs have been identified as playing a role in skeletal diseases, e.g. osteoporosis and osteoarthritis $(\mathrm{OA})(117,118)$. A novel miRNA, miR2861, was identified by Li et al. (63) to contribute to osteoporosis in mice and humans. miR-2861 promoted osteoblast differentiation by targeting HDAC5 and thereby increasing levels of Runx2. In vivo silencing of miR-2861 inhibited bone formation and resulted in decreased bone mass in mice. Consistently, mutations in pre-miR-2861 were associated with early osteoporosis in humans. Not only mutations in the miRNA gene but also in the 3'-UTR of the target gene can predispose to diseases such as osteoporosis (119). Polymorphisms in the 3'-UTR may alter miRNA binding leading to dysregulation of the target gene and aberrant protein level. By comparing known polymorphisms in miRNA target sites (poly-miRTSs) and osteoporosis, Lei et al. recently discovered three polymorphisms in the FGF2 gene that were significantly associated with femoral neck bone mineral density (BMD). These poly-miRTSs harboured binding sites for nine miRs whose binding is potentially altered due to polymorphisms, which can contribute to susceptibility to osteoporosis.

Besides playing a role in osteoporosis, miRNAs are associated with destructive joint diseases such as OA and rheumatoid arthritis (RA). miR-140 has been shown to be highly expressed in normal human articular cartilage, and the expression is reduced in OA (120). Disruption of miR-140 predisposed to age-related OA and, conversely, its over-expression in chondrocytes protected from OA, indicating that miR-140 prevents development of the disease by a mechanism that may involve regulation of ADAMTS5 (121). MiR-146a has been associated with both $\mathrm{OA}$ and RA $(122,123,124)$. It is a negative regulator of inflammatory and innate immune responses and was recently discovered to inhibit osteoclastogenesis $(125,126)$. These studies suggest that miRNAs play important roles in the articular cartilage pathology and skeletal homeostasis in vivo.

miRNA targeting represents a novel therapeutic opportunity for treatment of osteoporosis and arthritis. Down-regulated miRNAs could be restored by overexpression using stable vector transfection or transient transfection by double-stranded miRNAs (ds miRNA). By artificial expression of a miRNA that is up-regulated during osteoblastic differentiation and osteogenesis, restoration of down-regulated miRNAs may be a potential treatment strategy in osteoporosis. This approach was applied to suppress bone and cartilage destruction in RA. In vivo administration of doublestranded miR-146a prevented joint destruction in arthritic mice, thus demonstrating potential as a therapeutic target for bone destruction in RA $(125,126)$.

Anti-miRs were used to investigate the in vivo function of miR-2861 in osteoporosis in mice. AntimiR-2861 was injected into the tail vein in sham operated or ovariectomised (OVX) mice. Inhibition of miR-2861 by anti-miR resulted in significantly reduced BMD, the bone loss being most severe in OVX mice (63). Another approach is to combine miRNA technology with stem cell therapy. MSCs are successfully used as vehicles in gene therapy in skeletal repair purposes (127). We recently demonstrated enhanced in vivo bone formation by functional inhibition of miR-138 in hMSCs using an LNA-modified anti-miR oligonucleotide (77). The approach in using MSCs as vehicles to deliver miRNA mimics or anti-miRs may serve as a potential tool in future bone regeneration applications.

\section{Future challenges}

miRNA based therapy is successfully used in several diseases and an increasing number of reports have been published with evidence of their potential use in skeletal conditions such as osteoporosis and arthritis. Although studies have shown promising results in using miRNAs in skeletal therapy, further investigation is required to better understand the advantages and limitations of this approach. In order to develop effective and safe delivery methods, localisation of ds miRNAs or anti-miRs uptake after systemic delivery should be identified. Designing cellor tissue-specific administration systems to avoid offtarget or even opposing effects in non-targeted tissues remains to be a challenge. Optimisation of delivery dose as well as potential use, whether as a combination of several miRNAs as a cocktail or with other biological agents, needs to be carefully investigated for each application.

\section{Conclusions and perspectives}

miRNAs are increasingly recognised as important regulatory molecules of a large number of biological 
functions. Understanding their expression profiles and dynamic regulation may be the key to enhance osteoblastic differentiation and bone formation in the treatment of pathological bone diseases. Recent advances in miRNA research have provided new perspectives on the regulation of skeletal development. Moreover, understanding the function of miRNAs and their association with the molecular pathogenesis of various diseases, including $\mathrm{OA}$ and osteoporosis, has provided novel insights into the development of therapeutic treatments. Using miRNAs as therapeutic targets by manipulating the miRNA levels to promote osteoblast differentiation may well become a powerful tool in the development of new therapeutic approaches. However, numerous questions including potential off-target effects and efficient delivery in vivo need to be solved before using miRNAs in bone disease therapeutics.

\section{Declaration of interest}

The authors declare that there is no conflict of interest that could be perceived as prejudicing the impartiality of the research reported.

\section{Funding}

This research did not receive any specific grant from any funding agency in the public, commercial or not-for-profit sector.

\section{References}

1 Ducy P, Schinke T \& Karsenty G. The osteoblast: a sophisticated fibroblast under central surveillance. Science $2000 \mathbf{2 8 9}$ 1501-1504. (doi:10.1126/science.289.5484.1501)

2 Sacchetti B, Funari A, Michienzi S, Di Cesare S, Piersanti S, Saggio I, Tagliafico E, Ferrari S, Robey PG, Riminucci M \& Bianco P. Self-renewing osteoprogenitors in bone marrow sinusoids can organize a hematopoietic microenvironment. Cell 2007131 324-336. (doi:10.1016/j.cell.2007.08.025)

3 Compston JE. Sex steroids and bone. Physiological Reviews 2001 81 419-447.

4 Poole KE \& Compston JE. Osteoporosis and its management. BMJ 2006333 1251-1256. (doi:10.1136/bmj.39050.597350.47)

5 Harada S \& Rodan GA. Control of osteoblast function and regulation of bone mass. Nature $2003 \mathbf{4 2 3}$ 349-355. (doi:10. 1038/nature01660)

6 Komori T. Regulation of osteoblast differentiation by transcription factors. Journal of Cellular Biochemistry 200699 1233-1239. (doi:10.1002/jcb.20958)

7 Nakashima K \& de Crombrugghe B. Transcriptional mechanisms in osteoblast differentiation and bone formation. Trends in Genetics 200319 458-466. (doi:10.1016/S0168-9525(03) 00176-8)

8 Canalis E. Growth factor control of bone mass. Journal of Cellular Biochemistry 2009108 769-777. (doi:10.1002/jcb.22322)

9 Chen D, Zhao M \& Mundy GR. Bone morphogenetic proteins. Growth Factors 200422 233-241. (doi:10.1080/08977190 412331279890)

$10 \mathrm{Hu}$ H, Hilton MJ, Tu X, Yu K, Ornitz DM \& Long F. Sequential roles of Hedgehog and Wnt signaling in osteoblast development. Development 2005132 49-60. (doi:10.1242/dev.01564)

11 Tezuka K, Yasuda M, Watanabe N, Morimura N, Kuroda K, Miyatani S \& Hozumi N. Stimulation of osteoblastic cell differentiation by Notch. Journal of Bone and Mineral Research 200217 231-239. (doi:10.1359/jbmr.2002.17.2.231)
12 Zamurovic N, Cappellen D, Rohner D \& Susa M. Coordinated activation of notch, Wnt, and transforming growth factor-beta signaling pathways in bone morphogenic protein 2-induced osteogenesis. Notch target gene Hey1 inhibits mineralization and Runx2 transcriptional activity. Journal of Biological Chemistry 2004279 37704-37715. (doi:10.1074/jbc.M403813200)

13 Kratchmarova I, Blagoev B, Haack-Sorensen M, Kassem M \& Mann M. Mechanism of divergent growth factor effects in mesenchymal stem cell differentiation. Science $2005 \mathbf{3 0 8}$ 1472-1477. (doi:10.1126/science.1107627)

14 Kapinas K \& Delany AM. MicroRNA biogenesis and regulation of bone remodeling. Arthritis Research and Therapy 201113220. (doi:10.1186/ar3325)

15 Venter JC, Adams MD, Myers EW, Li PW, Mural RJ, Sutton GG, Smith HO, Yandell M, Evans CA, Holt RA, Gocayne JD, Amanatides P, Ballew RM, Huson DH, Wortman JR, Zhang Q, Kodira CD, Zheng XH, Chen L, Skupski M, Subramanian G, Thomas PD, Zhang J, Gabor Miklos GL, Nelson C, Broder S, Clark AG, Nadeau J, McKusick VA, Zinder N, Levine AJ, Roberts RJ, Simon M, Slayman C, Hunkapiller M, Bolanos R, Delcher A, Dew I, Fasulo D, Flanigan M, Florea L, Halpern A, Hannenhalli S, Kravitz S, Levy S, Mobarry C, Reinert K, Remington K, Abu-Threideh J, Beasley E, Biddick K, Bonazzi V, Brandon R, Cargill M, Chandramouliswaran I, Charlab R, Chaturvedi K, Deng Z, DiFrancesco V, Dunn P, Eilbeck K, Evangelista C, Gabrielian AE, Gan W, Ge W, Gong F, Gu Z, Guan P, Heiman TJ, Higgins ME, Ji RR, Ke Z, Ketchum KA, Lai Z, Lei Y, Li Z, Li J, Liang Y, Lin X, Lu F, Merkulov GV, Milshina N, Moore HM, Naik AK, Narayan VA, Neelam B, Nusskern D, Rusch DB, Salzberg S, Shao W, Shue B, Sun J, Wang Z, Wang A, Wang X, Wang J, Wei M, Wides R, Xiao C, Yan C, Yao A, Ye J, Zhan M, Zhang W, Zhang H, Zhao Q, Zheng L, Zhong F, Zhong W, Zhu S, Zhao S, Gilbert D, Baumhueter S, Spier G, Carter C, Cravchik A, Woodage T, Ali F, An H, Awe A, Baldwin D, Baden H, Barnstead M, Barrow I, Beeson K, Busam D, Carver A, Center A, Cheng ML, Curry L, Danaher S, Davenport L, Desilets R, Dietz S, Dodson K, Doup L, Ferriera S, Garg N, Gluecksmann A, Hart B, Haynes J, Haynes C, Heiner C, Hladun S, Hostin D, Houck J, Howland T, Ibegwam C, Johnson J, Kalush F, Kline L, Koduru S, Love A, Mann F, May D, McCawley S, McIntosh T, McMullen I, Moy M, Moy L, Murphy B, Nelson K, Pfannkoch C, Pratts E, Puri V, Qureshi H, Reardon M, Rodriguez R, Rogers YH, Romblad D, Ruhfel B, Scott R, Sitter C, Smallwood M, Stewart E, Strong R, Suh E, Thomas R, Tint NN, Tse S, Vech C, Wang G, Wetter J, Williams S, Williams M, Windsor S, WinnDeen E, Wolfe K, Zaveri J, Zaveri K, Abril JF, Guigó R, Campbell MJ, Sjolander KV, Karlak B, Kejariwal A, Mi H, Lazareva B, Hatton T, Narechania A, Diemer K, Muruganujan A, Guo N, Sato S, Bafna V, Istrail S, Lippert R, Schwartz R, Walenz B, Yooseph S, Allen D, Basu A, Baxendale J, Blick L, Caminha M, Carnes-Stine J, Caulk P, Chiang YH, Coyne M, Dahlke C, Mays A, Dombroski M, Donnelly M, Ely D, Esparham S, Fosler C, Gire H, Glanowski S, Glasser K, Glodek A, Gorokhov M, Graham K, Gropman B, Harris M, Heil J, Henderson S, Hoover J, Jennings D, Jordan C, Jordan J, Kasha J, Kagan L, Kraft C, Levitsky A, Lewis M, Liu X, Lopez J, Ma D, Majoros W, McDaniel J, Murphy S, Newman M, Nguyen T, Nguyen N, Nodell M, Pan S, Peck J, Peterson M, Rowe W, Sanders R, Scott J, Simpson M, Smith T, Sprague A, Stockwell T, Turner R, Venter E, Wang M, Wen M, Wu D, Wu M, Xia A, Zandieh A \& Zhu X. The sequence of the human genome. Science 2001291 1304-1351. (doi:10.1126/science.1058040)

16 Mattick JS \& Makunin IV. Non-coding RNA. Human Molecular Genetics 200615 R17-R29. (doi:10.1093/hmg/ddl046)

17 Lau NC, Lim LP, Weinstein EG \& Bartel DP. An abundant class of tiny RNAs with probable regulatory roles in Caenorhabditis elegans. Science 2001294 858-862. (doi:10.1126/science. 1065062)

18 Lee RC \& Ambros V. An extensive class of small RNAs in Caenorhabditis elegans. Science 2001294 862-864. (doi:10. 1126/science.1065329) 
19 Lee RC, Feinbaum RL \& Ambros V. The C. elegans heterochronic gene lin- 4 encodes small RNAs with antisense complementarity to lin-14. Cell 199375 843-854. (doi:10.1016/0092-8674 (93) $90529-\mathrm{Y})$

20 Bartel DP. MicroRNAs: genomics, biogenesis, mechanism, and function. Cell 2004116 281-297. (doi:10.1016/S0092-8674 (04)00045-5)

21 Lai EC. Micro RNAs are complementary to $3^{\prime}$ UTR sequence motifs that mediate negative post-transcriptional regulation. Nature Genetics 200230 363-364. (doi:10.1038/ng865)

22 Lagos-Quintana M, Rauhut R, Meyer J, Borkhardt A \& Tuschl T. New microRNAs from mouse and human. RNA $2003 \mathbf{9}$ 175-179. (doi:10.1261/rna.2146903)

23 Lai EC, Tomancak P, Williams RW \& Rubin GM. Computational identification of Drosophila microRNA genes. Genome Biology 20034 R42. (doi:10.1186/gb-2003-4-7-r42)

24 Girijadevi R, Sreedevi VC, Sreedharan JV \& Pillai MR. IntmiR: a complete catalogue of intronic miRNAs of human and mouse. Bioinformation $20115458-459$.

25 Lagos-Quintana M, Rauhut R, Lendeckel W \& Tuschl T. Identification of novel genes coding for small expressed RNAs. Science 2001294 853-858. (doi:10.1126/science.1064921)

26 Lee Y, Jeon K, Lee JT, Kim S \& Kim VN. MicroRNA maturation: stepwise processing and subcellular localization. EMBO Journal 200221 4663-4670. (doi:10.1093/emboj/cdf476)

27 Lee Y, Kim M, Han J, Yeom KH, Lee S, Baek SH \& Kim VN. MicroRNA genes are transcribed by RNA polymerase II. EMBO Journal 200423 4051-4060. (doi:10.1038/sj.emboj.7600385)

28 Zeng Y, Yi R \& Cullen BR. Recognition and cleavage of primary microRNA precursors by the nuclear processing enzyme Drosha. EMBO Journal 200524 138-148. (doi:10.1038/sj.emboj. $7600491)$

29 Denli AM, Tops BB, Plasterk RH, Ketting RF \& Hannon GJ. Processing of primary microRNAs by the microprocessor complex. Nature 2004432 231-235. (doi:10.1038/nature03049)

30 Landthaler M, Yalcin A \& Tuschl T. The human DiGeorge syndrome critical region gene 8 and its D. melanogaster homolog are required for miRNA biogenesis. Current Biology $2004 \mathbf{1 4}$ 2162-2167. (doi:10.1016/j.cub.2004.11.001)

31 Lee Y, Ahn C, Han J, Choi H, Kim J, Yim J, Lee J, Provost P, Radmark O, Kim S \& Kim VN. The nuclear RNase III Drosha initiates microRNA processing. Nature $2003 \mathbf{4 2 5} 415-419$. (doi:10.1038/nature01957)

32 Lund E, Guttinger S, Calado A, Dahlberg JE \& Kutay U. Nuclear export of microRNA precursors. Science 2004303 95-98. (doi:10.1126/science.1090599)

33 Yi R, Oin Y, Macara IG \& Cullen BR. Exportin-5 mediates the nuclear export of pre-microRNAs and short hairpin RNAs. Genes and Development 200317 3011-3016. (doi:10.1101/gad. 1158803)

34 Hutvagner G, McLachlan J, Pasquinelli AE, Balint E, Tuschl T \& Zamore PD. A cellular function for the RNA-interference enzyme Dicer in the maturation of the let-7 small temporal RNA. Science 2001293 834-838. (doi:10.1126/science.1062961)

35 Ding XC, Weiler J \& Grosshans H. Regulating the regulators: mechanisms controlling the maturation of microRNAs. Trends in Biotechnology 200927 27-36. (doi:10.1016/j.tibtech.2008.09. 006)

36 Bosse GD \& Simard MJ. A new twist in the microRNA pathway: not Dicer but Argonaute is required for a microRNA production. Cell Research 201020 735-737. (doi:10.1038/cr.2010.83)

37 Hutvagner G \& Simard MJ. Argonaute proteins: key players in RNA silencing. Nature Reviews. Molecular Cell Biology 20089 22-32. (doi:10.1038/nrm2321)

38 Bartel DP. MicroRNAs: target recognition and regulatory functions. Cell 2009136 215-233. (doi:10.1016/j.cell.2009. 01.002)

39 Lewis BP, Burge CB \& Bartel DP. Conserved seed pairing, often flanked by adenosines, indicates that thousands of human genes are microRNA targets. Cell 2005120 15-20. (doi:10.1016/j. cell.2004.12.035)
40 Giraldez AJ, Mishima Y, Rihel J, Grocock RJ, Van Dongen S, Inoue K, Enright AJ \& Schier AF. Zebrafish MiR-430 promotes deadenylation and clearance of maternal mRNAs. Science 2006 312 75-79. (doi:10.1126/science.1122689)

41 Pillai RS, Bhattacharyya SN, Artus CG, Zoller T, Cougot N, Basyuk E, Bertrand E \& Filipowicz W. Inhibition of translational initiation by Let-7 microRNA in human cells. Science 2005309 1573-1576. (doi:10.1126/science.1115079)

42 Zeng Y \& Cullen BR. Sequence requirements for micro RNA processing and function in human cells. RNA 20039 112-123. (doi:10.1261/rna.2780503)

43 Guo H, Ingolia NT, Weissman JS \& Bartel DP. Mammalian microRNAs predominantly act to decrease target mRNA levels. Nature 2010466 835-840. (doi:10.1038/nature09267)

44 Kozomara A \& Griffiths-Jones S. miRBase: integrating microRNA annotation and deep-sequencing data. Nucleic Acids Research 201139 D152-D157. (doi:10.1093/nar/gkq1027)

45 Lim LP, Lau NC, Garrett-Engele P, Grimson A, Schelter JM, Castle J, Bartel DP, Linsley PS \& Johnson JM. Microarray analysis shows that some microRNAs downregulate large numbers of target mRNAs. Nature $2005 \mathbf{4 3 3}$ 769-773. (doi:10.1038/ nature03315)

46 Friedman RC, Farh KK, Burge CB \& Bartel DP. Most mammalian mRNAs are conserved targets of microRNAs. Genome Research 200919 92-105. (doi:10.1101/gr.082701.108)

47 Chen C, Ridzon DA, Broomer AJ, Zhou Z, Lee DH, Nguyen JT, Barbisin M, Xu NL, Mahuvakar VR, Andersen MR, Lao KQ, Livak KJ \& Guegler KJ. Real-time quantification of microRNAs by stem-loop RT-PCR. Nucleic Acids Research 200533 e179. (doi:10. 1093/nar/gni178)

48 Inui M, Martello G \& Piccolo S. MicroRNA control of signal transduction. Nature Reviews. Molecular Cell Biology 201011 252-263. (doi:10.1038/nrm2868)

49 Caruso P, MacLean MR, Khanin R, McClure J, Soon E, Southgate M, MacDonald RA, Greig JA, Robertson KE, Masson R, Denby L, Dempsie Y, Long L, Morrell NW \& Baker AH. Dynamic changes in lung microRNA profiles during the development of pulmonary hypertension due to chronic hypoxia and monocrotaline. Arteriosclerosis, Thrombosis, and Vascular Biology 201030 716-723. (doi:10.1161/ATVBAHA. 109.202028)

50 Hwang HW \& Mendell JT. MicroRNAs in cell proliferation, cell death, and tumorigenesis. British Journal of Cancer 200694 776-780. (doi:10.1038/sj.bjc.6603023)

51 Stark KL, Xu B, Bagchi A, Lai WS, Liu H, Hsu R, Wan X, Pavlidis P, Mills AA, Karayiorgou M \& Gogos JA. Altered brain microRNA biogenesis contributes to phenotypic deficits in a 22q11-deletion mouse model. Nature Genetics $2008 \mathbf{4 0}$ 751-760. (doi:10.1038/ng.138)

52 van Rooij E, Sutherland LB, Liu N, Williams AH, McAnally J, Gerard RD, Richardson JA \& Olson EN. A signature pattern of stress-responsive microRNAs that can evoke cardiac hypertrophy and heart failure. PNAS $2006 \mathbf{1 0 3}$ 18255-18260. (doi:10. 1073/pnas.0608791103)

53 Esquela-Kerscher A \& Slack FJ. Oncomirs - microRNAs with a role in cancer. Nature Reviews. Cancer 20066 259-269. (doi:10. $1038 / \mathrm{nrc1} 840)$

54 Lu J, Getz G, Miska EA, Alvarez-Saavedra E, Lamb J. Peck D, Sweet-Cordero A, Ebert BL, Mak RH, Ferrando AA, Downing JR, Jacks T, Horvitz HR \& Golub TR. MicroRNA expression profiles classify human cancers. Nature 2005435 834-838. (doi:10. 1038/nature03702)

55 Bernstein E, Kim SY, Carmell MA, Murchison EP, Alcorn H, Li MZ, Mills AA, Elledge SJ, Anderson KV \& Hannon GJ. Dicer is essential for mouse development. Nature Genetics 200335 215-217. (doi:10.1038/ng1253)

56 Liu J, Carmell MA, Rivas FV, Marsden CG, Thomson JM, Song JJ, Hammond SM, Joshua-Tor L \& Hannon GJ. Argonaute2 is the catalytic engine of mammalian RNAi. Science 2004305 1437-1441. (doi:10.1126/science.1102513) 
57 Kloosterman WP \& Plasterk RH. The diverse functions of microRNAs in animal development and disease. Developmental Cell 200611 441-450. (doi:10.1016/j.devcel.2006.09.009)

58 Kobayashi T, Lu J, Cobb BS, Rodda SJ, McMahon AP, Schipani E, Merkenschlager M \& Kronenberg HM. Dicer-dependent pathways regulate chondrocyte proliferation and differentiation. PNAS 2008105 1949-1954. (doi:10.1073/pnas.0707900105)

59 Heimberg AM, Sempere LF, Moy VN, Donoghue PC \& Peterson KJ. MicroRNAs and the advent of vertebrate morphological complexity. PNAS 2008105 2946-2950. (doi:10.1073/pnas. 0712259105)

60 Kim VN, Han J \& Siomi MC. Biogenesis of small RNAs in animals. Nature Reviews. Molecular Cell Biology 200910 126-139. (doi:10.1038/nrm2632)

61 Ventura A, Young AG, Winslow MM, Lintault L, Meissner A, Erkeland SJ, Newman J, Bronson RT, Crowley D, Stone JR, Jaenisch R, Sharp PA \& Jacks T. Targeted deletion reveals essential and overlapping functions of the miR-17 through 92 family of miRNA clusters. Cell 2008132 875-886. (doi:10.1016/j.cell. 2008.02.019)

62 Lee I, Ajay SS, Yook JI, Kim HS, Hong SH, Kim NH, Dhanasekaran SM, Chinnaiyan AM \& Athey BD. New class of microRNA targets containing simultaneous $5^{\prime}$-UTR and $3^{\prime}$-UTR interaction sites. Genome Research 200919 1175-1183. (doi:10. 1101/gr.089367.108)

63 Li H, Xie H, Liu W, Hu R, Huang B, Tan YF, Xu K, Sheng ZF, Zhou HD, Wu XP \& Luo XH. A novel microRNA targeting HDAC5 regulates osteoblast differentiation in mice and contributes to primary osteoporosis in humans. Journal of Clinical Investigation 2009119 3666-3677. (doi:10.1172/JCI39832)

64 Lytle JR, Yario TA \& Steitz JA. Target mRNAs are repressed as efficiently by microRNA-binding sites in the $5^{\prime}$ UTR as in the 3' UTR. PNAS 2007 104 9667-9672. (doi:10.1073/pnas. 0703820104)

65 Tay Y, Zhang J, Thomson AM, Lim B \& Rigoutsos I. MicroRNAs to Nanog, Oct4 and Sox 2 coding regions modulate embryonic stem cell differentiation. Nature $2008 \mathbf{4 5 5} 1124-1128$. (doi:10. 1038/nature07299)

66 Vasudevan S, Tong Y \& Steitz JA. Switching from repression to activation: microRNAs can up-regulate translation. Science 2007 318 1931-1934. (doi:10.1126/science.1149460)

67 Rajewsky N. microRNA target predictions in animals. Nature Genetics 200638 (Suppl) S8-S13. (doi:10.1038/ng1798)

68 Karginov FV, Conaco C, Xuan Z, Schmidt BH, Parker JS, Mandel G \& Hannon GJ. A biochemical approach to identifying microRNA targets. PNAS $2007 \mathbf{1 0 4} 19291-19296$. (doi:10.1073/pnas. 0709971104)

69 Chi SW, Zang JB, Mele A \& Darnell RB. Argonaute HITS-CLIP decodes microRNA-mRNA interaction maps. Nature 2009460 479-486.

70 Hafner M, Landthaler M, Burger L, Khorshid M, Hausser J, Berninger $\mathrm{P}$, Rothballer A, Ascano M Jr, Jungkamp AC, Munschauer M, Ulrich A, Wardle GS, Dewell S, Zavolan M \& Tuschl T. Transcriptome-wide identification of RNA-binding protein and microRNA target sites by PAR-CLIP. Cell $2010 \mathbf{1 4 1}$ 129-141. (doi:10.1016/j.cell.2010.03.009)

71 Hassan MQ, Gordon JA, Lian JB, van Wijnen AJ, Stein JL \& Stein GS. Ribonucleoprotein immunoprecipitation (RNP-IP): a direct in vivo analysis of microRNA-targets. Journal of Cellular Biochemistry $2010110817-822$. (doi:10.1002/jcb.22562)

72 Li Z, Hassan MQ, Jafferji M, Aqeilan RI, Garzon R, Croce CM, van Wijnen AJ, Stein JL, Stein GS \& Lian JB. Biological functions of miR-29b contribute to positive regulation of osteoblast differentiation. Journal of Biological Chemistry 2009 284 15676-15684. (doi:10.1074/jbc.M809787200)

73 Liu CG, Calin GA, Meloon B, Gamliel N, Sevignani C, Ferracin M, Dumitru CD, Shimizu M, Zupo S, Dono M, Alder H, Bullrich F, Negrini $M$ \& Croce CM. An oligonucleotide microchip for genome-wide microRNA profiling in human and mouse tissues. PNAS $2004 \quad 101$ 9740-9744. (doi:10.1073/pnas.040329 3101)
74 Inose H, Ochi H, Kimura A, Fujita K, Xu R, Sato S, Iwasaki M, Sunamura S, Takeuchi Y, Fukumoto S, Saito K, Nakamura T, Siomi H, Ito H, Arai Y, Shinomiya K \& Takeda S. A microRNA regulatory mechanism of osteoblast differentiation. PNAS 2009 106 20794-20799. (doi:10.1073/pnas.0909311106)

75 Li Z, Hassan MQ, Volinia S, van Wijnen AJ, Stein JL, Croce CM, Lian JB \& Stein GS. A microRNA signature for a BMP2-induced osteoblast lineage commitment program. PNAS $2008 \mathbf{1 0 5}$ 13906-13911. (doi:10.1073/pnas.0804438105)

76 Castoldi M, Schmidt S, Benes V, Noerholm M, Kulozik AE, Hentze MW \& Muckenthaler MU. A sensitive array for microRNA expression profiling (miChip) based on locked nucleic acids (LNA). RNA 200612 913-920. (doi:10.1261/rna.2332406)

77 Eskildsen T, Taipaleenmaki H, Stenvang J, Abdallah BM, Ditzel N, Nossent AY, Bak M, Kauppinen S \& Kassem M. MicroRNA-138 regulates osteogenic differentiation of human stromal (mesenchymal) stem cells in vivo. PNAS 2011108 6139-6144. (doi:10. 1073/pnas.1016758108)

78 Zhang J, Tu Q, Bonewald LF, He X, Stein G, Lian J \& Chen J. Effects of miR-335-5p in modulating osteogenic differentiation by specifically down-regulating Wnt antagonist DKK1. Journal of Bone and Mineral Research 201126 1953-1963. (doi:10.1002/ jbmr.377)

79 Berezikov E, Thuemmler F, van Laake LW, Kondova I, Bontrop R, Cuppen E \& Plasterk RH. Diversity of microRNAs in human and chimpanzee brain. Nature Genetics $2006 \quad 38$ 1375-1377. (doi:10.1038/ng1914)

80 Willenbrock H, Salomon J, Sokilde R, Barken KB, Hansen TN, Nielsen FC, Moller $\mathrm{S} \&$ Litman T. Quantitative miRNA expression analysis: comparing microarrays with next-generation sequencing. RNA 200915 2028-2034. (doi:10.1261/rna. 1699809)

81 Friedlander MR, Chen W, Adamidi C, Maaskola J, Einspanier R, Knespel S \& Rajewsky N. Discovering microRNAs from deep sequencing data using miRDeep. Nature Biotechnology 200826 407-415. (doi:10.1038/nbt1394)

82 Hackenberg M, Sturm M, Langenberger D, Falcon-Perez JM \& Aransay AM. miRanalyzer: a microRNA detection and analysis tool for next-generation sequencing experiments. Nucleic Acids Research 200937 W68-W76. (doi:10.1093/nar/gkp347)

83 Wienholds E, Kloosterman WP, Miska E, Alvarez-Saavedra E, Berezikov E, de Bruijn E, Horvitz HR, Kauppinen S \& Plasterk RH. MicroRNA expression in zebrafish embryonic development. Science 2005309 310-311. (doi:10.1126/science.1114519)

84 Giustina A, Mazziotti G \& Canalis E. Growth hormone, insulinlike growth factors, and the skeleton. Endocrine Reviews 200829 535-559. (doi:10.1210/er.2007-0036)

85 Locklin RM, Oreffo RO \& Triffitt JT. Effects of TGFbeta and bFGF on the differentiation of human bone marrow stromal fibroblasts. Cell Biology International 199923 185-194. (doi:10.1006/cbir. 1998.0338)

86 Okamoto M, Murai J, Yoshikawa H \& Tsumaki N. Bone morphogenetic proteins in bone stimulate osteoclasts and osteoblasts during bone development. Journal of Bone and Mineral Research 200621 1022-1033. (doi:10.1359/jbmr.060411)

87 Ducy P, Zhang R, Geoffroy V, Ridall AL \& Karsenty G. Osf2/Cbfa1: a transcriptional activator of osteoblast differentiation. Cell 1997 89 747-754. (doi:10.1016/S0092-8674(00)80257-3)

88 Komori T, Yagi H, Nomura S, Yamaguchi A, Sasaki K, Deguchi K, Shimizu Y, Bronson RT, Gao YH, Inada M, Sato M, Okamoto R, Kitamura Y, Yoshiki S \& Kishimoto T. Targeted disruption of Cbfa1 results in a complete lack of bone formation owing to maturational arrest of osteoblasts. Cell $1997 \mathbf{8 9} 755-764$. (doi:10.1016/S0092-8674(00)80258-5)

89 Ducy P, Starbuck M, Priemel M, Shen J, Pinero G, Geoffroy V, Amling M \& Karsenty G. A Cbfa1-dependent genetic pathway controls bone formation beyond embryonic development. Genes and Development 199913 1025-1036. (doi:10.1101/gad.13.8. 1025) 
90 Karsenty G, Ducy P, Starbuck M, Priemel M, Shen J, Geoffroy V \& Amling M. Cbfa1 as a regulator of osteoblast differentiation and function. Bone 199925 107-108. (doi:10.1016/S87563282(99)00111-8)

91 Nakashima K, Zhou X, Kunkel G, Zhang Z, Deng JM, Behringer RR \& de Crombrugghe B. The novel zinc fingercontaining transcription factor osterix is required for osteoblast differentiation and bone formation. Cell 2002108 17-29. (doi:10.1016/S0092-8674(01)00622-5)

92 Marie PJ. Transcription factors controlling osteoblastogenesis. Archives of Biochemistry and Biophysics 2008 473 98-105. (doi:10.1016/j.abb.2008.02.030)

93 Huang J, Zhao L, Xing L \& Chen D. MicroRNA-204 regulates Runx2 protein expression and mesenchymal progenitor cell differentiation. Stem Cells 201028 357-364.

94 Zhang Y, Xie RL, Croce CM, Stein JL, Lian JB, van Wijnen AJ \& Stein GS. A program of microRNAs controls osteogenic lineage progression by targeting transcription factor Runx2. PNAS 2011 108 9863-9868. (doi:10.1073/pnas.1018493108)

95 Salasznyk RM, Klees RF, Williams WA, Boskey A \& Plopper GE. Focal adhesion kinase signaling pathways regulate the osteogenic differentiation of human mesenchymal stem cells. Experimental Cell Research 2007313 22-37. (doi:10.1016/j. yexcr.2006.09.013)

96 Young SR, Gerard-O'Riley R, Kim JB \& Pavalko FM. Focal adhesion kinase is important for fluid shear stress-induced mechanotransduction in osteoblasts. Journal of Bone and Mineral Research 200924 411-424. (doi:10.1359/jbmr.081102)

97 Luzi E, Marini F, Sala SC, Tognarini I, Galli G \& Brandi ML. Osteogenic differentiation of human adipose tissue-derived stem cells is modulated by the miR-26a targeting of the SMAD1 transcription factor. Journal of Bone and Mineral Research 200823 287-295. (doi:10.1359/jbmr.071011)

98 Yang Z, Bian C, Zhou H, Huang S, Wang S, Liao L \& Zhao RC. MicroRNA hsa-miR-138 inhibits adipogenic differentiation of human adipose tissue-derived mesenchymal stem cells through adenovirus EID-1. Stem Cells and Development 201120 259-267. (doi:10.1089/scd.2010.0072)

99 Tome M, Lopez-Romero P, Albo C, Sepulveda JC, FernandezGutierrez B, Dopazo A, Bernad A \& Gonzalez MA. miR-335 orchestrates cell proliferation, migration and differentiation in human mesenchymal stem cells. Cell Death and Differentiation 201118 985-995. (doi:10.1038/cdd.2010.167)

100 Zhang JF, Fu WM, He ML, Wang H, Wang WM, Yu SC, Bian XW, Zhou J, Lin MC, Lu G, Poon WS \& Kung HF. MiR-637 maintains the balance between adipocytes and osteoblasts by directly targeting osterix. Molecular Biology of the Cell 201122 3955-3961. (doi:10.1091/mbc.E11-04-0356)

101 Itoh T, Nozawa Y \& Akao Y. MicroRNA-141 and -200a are involved in bone morphogenetic protein-2-induced mouse preosteoblast differentiation by targeting distal-less homeobox 5 . Journal of Biological Chemistry $2009 \mathbf{2 8 4} 19272-19279$. (doi:10. 1074/jbc.M109.014001)

102 Kapinas K, Kessler CB \& Delany AM. miR-29 suppression of osteonectin in osteoblasts: regulation during differentiation and by canonical Wnt signaling. Journal of Cellular Biochemistry 2009 108 216-224. (doi:10.1002/jcb.22243)

103 Kapinas K, Kessler C, Ricks T, Gronowicz G \& Delany AM. miR-29 modulates Wht signaling in human osteoblasts through a positive feedback loop. Journal of Biological Chemistry 2010285 25221-25231. (doi:10.1074/jbc.M110.116137)

$104 \mathrm{Hu} \mathrm{R}$, Liu W, Li H, Yang L, Chen C, Xia ZY, Guo LJ, Xie H, Zhou HD, Wu XP \& Luo XH. A Runx2/miR-3960/miR-2861 regulatory feedback loop during mouse osteoblast differentiation. Journal of Biological Chemistry 2011286 12328-12339. (doi:10. 1074/jbc.M110.176099)

105 Hassan MQ, Gordon JA, Beloti MM, Croce CM, van Wijnen AJ, Stein JL, Stein GS \& Lian JB. A network connecting Runx2, SATB2, and the miR-23a $27 \mathrm{a} \sim 24-2$ cluster regulates the osteoblast differentiation program. PNAS $2010 \quad \mathbf{1 0 7}$ 19879-19884. (doi:10.1073/pnas.1007698107)
106 Kim YJ, Bae SW, Yu SS, Bae YC \& Jung JS. miR-196a regulates proliferation and osteogenic differentiation in mesenchymal stem cells derived from human adipose tissue. Journal of Bone and Mineral Research 200924 816-825. (doi:10.1359/jbmr. 081230)

107 Mizuno Y, Tokuzawa Y, Ninomiya Y, Yagi K, Yatsuka-Kanesaki Y, Suda T, Fukuda T, Katagiri T, Kondoh Y, Amemiya T, Tashiro H \& Okazaki Y. miR-210 promotes osteoblastic differentiation through inhibition of AcvR1b. FEBS Letters $2009 \mathbf{5 8 3}$ 2263-2268. (doi:10.1016/j.febslet.2009.06.006)

108 Schoolmeesters A, Eklund T, Leake D, Vermeulen A, Smith Q, Force Aldred S \& Fedorov Y. Functional profiling reveals critical role for miRNA in differentiation of human mesenchymal stem cells. PLoS ONE 20094 e5605. (doi:10.1371/journal.pone. 0005605)

109 Tuddenham L, Wheeler G, Ntounia-Fousara S, Waters J, Hajihosseini MK, Clark I \& Dalmay T. The cartilage specific microRNA-140 targets histone deacetylase 4 in mouse cells. FEBS Letters $2006 \mathbf{5 8 0}$ 4214-4217. (doi:10.1016/j.febslet. 2006.06.080)

110 Gaur T, Hussain S, Mudhasani R, Parulkar I, Colby JL, Frederick D, Kream BE, van Wijnen AJ, Stein JL, Stein GS, Jones SN \& Lian JB. Dicer inactivation in osteoprogenitor cells compromises fetal survival and bone formation, while excision in differentiated osteoblasts increases bone mass in the adult mouse. Developmental Biology 2010340 10-21. (doi:10.1016/ j.ydbio.2010.01.008)

111 Montgomery RL, Hullinger TG, Semus HM, Dickinson BA, Seto AG, Lynch JM, Stack C, Latimer PA, Olson EN \& van Rooij E. Therapeutic inhibition of miR-208a improves cardiac function and survival during heart failure. Circulation $2011 \mathbf{1 2 4}$ 1537-1547. (doi:10.1161/CIRCULATIONAHA.111.030932)

112 Brummelkamp TR, Bernards R \& Agami R. A system for stable expression of short interfering RNAs in mammalian cells. Science 2002296 550-553. (doi:10.1126/science.1068999)

113 Ebert MS, Neilson JR \& Sharp PA. MicroRNA sponges: competitive inhibitors of small RNAs in mammalian cells. Nature Methods 20074 721-726. (doi:10.1038/nmeth1079)

114 Elmen J, Lindow M, Schutz S, Lawrence M, Petri A, Obad S, Lindholm M, Hedtjarn M, Hansen HF, Berger U, Gullans S, Kearney P, Sarnow P, Straarup EM \& Kauppinen S. LNAmediated microRNA silencing in non-human primates. Nature 2008452 896-899. (doi:10.1038/nature06783)

115 Jopling CL, Yi M, Lancaster AM, Lemon SM \& Sarnow P. Modulation of hepatitis $\mathrm{C}$ virus RNA abundance by a liverspecific microRNA. Science 2005309 1577-1581. (doi:10. $1126 /$ science.1113329)

116 Lanford RE, Hildebrandt-Eriksen ES, Petri A, Persson R, Lindow M, Munk ME, Kauppinen S \& Orum H. Therapeutic silencing of microRNA-122 in primates with chronic hepatitis C virus infection. Science 2010327 198-201. (doi:10.1126/ science.1178178)

117 Jones SW, Watkins G, Le Good N, Roberts S, Murphy CL, Brockbank SM, Needham MR, Read SJ \& Newham P. The identification of differentially expressed microRNA in osteoarthritic tissue that modulate the production of TNF-alpha and MMP13. Osteoarthritis and Cartilage 200917 464-472. (doi:10. 1016/j.joca.2008.09.012)

118 Price S. Bone: novel microRNA expressed in osteoblasts promotes bone formation. Nature Reviews. Rheumatology 2010664. (doi:10.1038/nrrheum.2009.268)

119 Lei SF, Papasian CJ \& Deng HW. Polymorphisms in predicted miRNA binding sites and osteoporosis. Journal of Bone and Mineral Research 201126 72-78. (doi:10.1002/jbmr.186)

120 Miyaki S, Nakasa T, Otsuki S, Grogan SP, Higashiyama R, Inoue A, Kato Y, Sato T, Lotz MK \& Asahara H. MicroRNA-140 is expressed in differentiated human articular chondrocytes and modulates interleukin-1 responses. Arthritis and Rheumatism 200960 2723-2730. (doi:10.1002/art.24745)

121 Miyaki S, Sato T, Inoue A, Otsuki S, Ito Y, Yokoyama S, Kato Y, Takemoto F, Nakasa T, Yamashita S, Takada S, Lotz MK, Ueno- 
Kudo H \& Asahara H. MicroRNA-140 plays dual roles in both cartilage development and homeostasis. Genes and Development 201024 1173-1185. (doi:10.1101/gad.1915510)

122 Nakasa T, Miyaki S, Okubo A, Hashimoto M, Nishida K, Ochi M \& Asahara H. Expression of microRNA-146 in rheumatoid arthritis synovial tissue. Arthritis and Rheumatism $2008 \mathbf{5 8} 1284-1292$. (doi:10.1002/art.23429)

123 Stanczyk J, Pedrioli DM, Brentano F, Sanchez-Pernaute O, Kolling C, Gay RE, Detmar M, Gay S \& Kyburz D. Altered expression of microRNA in synovial fibroblasts and synovial tissue in rheumatoid arthritis. Arthritis and Rheumatism $2008 \mathbf{5 8}$ 1001-1009. (doi:10.1002/art.23386)

124 Yamasaki K, Nakasa T, Miyaki S, Ishikawa M, Deie M, Adachi N, Yasunaga Y, Asahara H \& Ochi M. Expression of microRNA-146a in osteoarthritis cartilage. Arthritis and Rheumatism 200960 1035-1041. (doi:10.1002/art.24404)

125 Nakasa T, Shibuya H, Nagata Y, Niimoto T \& Ochi M. The inhibitory effect of microRNA-146a expression on bone destruction in collagen-induced arthritis. Arthritis and Rheumatism 2011 63 1582-1590. (doi:10.1002/art.30321)

126 Pauley KM \& Cha S. miRNA-146a in rheumatoid arthritis: a new therapeutic strategy. Immunotherapy 20113 829-831. (doi:10. 2217/imt.11.70)

127 Abdallah BM \& Kassem M. The use of mesenchymal (skeletal) stem cells for treatment of degenerative diseases: current status and future perspectives. Journal of Cellular Physiology 2009218 9-12. (doi:10.1002/jcp.21572)

128 Goff LA, Boucher S, Ricupero CL, Fenstermacher S, Swerdel M, Chase LG, Adams CC, Chesnut J, Lakshmipathy U \& Hart RP. Differentiating human multipotent mesenchymal stromal cells regulate microRNAs: prediction of microRNA regulation by PDGF during osteogenesis. Experimental Hematology $2008 \mathbf{3 6}$ 1354-1369. (doi:10.1016/j.exphem.2008.05.004)

129 He J, Zhang JF, Yi C, Lv Q, Xie WD, Li JN, Wan G, Cui K, Kung HF, Yang J, Yang BB \& Zhang Y. miRNA-mediated functional changes through co-regulating function related genes. PLoS ONE 20105 e13558. (doi:10.1371/journal.pone.0013558)

130 Wang T \& Xu Z. miR-27 promotes osteoblast differentiation by modulating Wnt signaling. Biochemical and Biophysical Research Communications $2010 \mathbf{4 0 2}$ 186-189. (doi:10.1016/j.bbrc. 2010.08.031)

131 Mizuno Y, Yagi K, Tokuzawa Y, Kanesaki-Yatsuka Y, Suda T, Katagiri T, Fukuda T, Maruyama M, Okuda A, Amemiya T, Kondoh Y, Tashiro H \& Okazaki Y. miR-125b inhibits osteoblastic differentiation by down-regulation of cell proliferation. Biochemical and Biophysical Research Communications 2008368 267-272. (doi:10.1016/j.bbrc.2008.01.073)

132 Schaap-Oziemlak AM, Raymakers RA, Bergevoet SM, Gilissen C, Jansen BJ, Adema GJ, Kogler G, le Sage C, Agami R, van der Reijden BA \& Jansen JH. MicroRNA hsa-miR-135b regulates mineralization in osteogenic differentiation of human unrestricted somatic stem cells. Stem Cells and Development 201019 877-885. (doi:10.1089/scd.2009.0112)

133 Cho HH, Shin KK, Kim YJ, Song JS, Kim JM, Bae YC, Kim CD \& Jung JS. NF-kappaB activation stimulates osteogenic differentiation of mesenchymal stem cells derived from human adipose tissue by increasing TAZ expression. Journal of Cellular Physiology 2010223 168-177. (doi:10.1002/jcp.22024)

134 Yin Q, Wang X, Fewell C, Cameron J, Zhu H, Baddoo M, Lin Z \& Flemington EK. MicroRNA miR-155 inhibits bone morphogenetic protein (BMP) signaling and BMP-mediated Epstein-Barr virus reactivation. Journal of Virology $2010 \mathbf{8 4} 6318-6327$. (doi:10.1128/JVI.00635-10)

135 Mizoguchi F, Izu Y, Hayata T, Hemmi H, Nakashima K, Nakamura T, Kato S, Miyasaka N, Ezura Y \& Noda M. Osteoclast-specific Dicer gene deficiency suppresses osteoclastic bone resorption. Journal of Cellular Biochemistry 2010109 866-875. (doi:10.1002/jcb.22228)

136 Lin EA, Kong L, Bai XH, Luan Y \& Liu CJ. miR-199a, a bone morphogenic protein 2-responsive microRNA, regulates chondrogenesis via direct targeting to Smad1. Journal of Biological Chemistry 2009 284 11326-11335. (doi:10.1074/jbc. M807709200)

137 Oskowitz AZ, Lu J, Penfornis P, Ylostalo J, McBride J, Flemington EK, Prockop DJ \& Pochampally R. Human multipotent stromal cells from bone marrow and microRNA: regulation of differentiation and leukemia inhibitory factor expression. PNAS $2008 \mathbf{1 0 5}$ 18372-18377. (doi:10.1073/ pnas.0809807105)

138 Sato MM, Nashimoto M, Katagiri T, Yawaka Y \& Tamura M. Bone morphogenetic protein-2 down-regulates miR-206 expression by blocking its maturation process. Biochemical and Biophysical Research Communications 2009383 125-129. (doi:10.1016/j. bbrc.2009.03.142)

139 Itoh T, Takeda S \& Akao Y. MicroRNA-208 modulates BMP-2stimulated mouse preosteoblast differentiation by directly targeting V-ets erythroblastosis virus E26 oncogene homolog 1. Journal of Biological Chemistry 2010285 27745-27752. (doi:10. 1074/jbc.M110.105080)

140 Kahai S, Lee SC, Lee DY, Yang J, Li M, Wang CH, Jiang Z, Zhang Y, Peng C \& Yang BB. MicroRNA miR-378 regulates nephronectin expression modulating osteoblast differentiation by targeting GalNT-7. PLoS ONE 20094 e7535. (doi:10.1371/journal.pone. $0007535)$

Received 22 July 2011

Revised version received 23 October 2011

Accepted 14 November 2011 